\title{
PENGARUH PIJAT BAYI TERHADAP PENINGKATAN FREKUENSI DAN DURASI MENYUSU PADA BAYI USIA 1 - 3 BULAN
}

\author{
INFLUENCE OF BABY MASSAGE ON IMPROVING FREQUENCY AND DURATION \\ OF FURNISHING IN BABY AGE 1 - 3 MONTHS
}

Farida Y, Mardianti, Komalasari L

Prodi Kebidanan Karawang, Poltekkes Kemenkes Bandung

Email: aliya.revana@gmail.com

\begin{abstract}
ABSTRAK
Salah satu dari manfaat pijat bayi adalah peningkatan nafsu makan ini ditambah dengan peningkatan aktivitas nervus vagus/saraf pengembara (system saraf otak yang bekerja untuk daerah leher ke bawah sampai dada dan rongga perut) dalam menggerakkan sel peristaltic (sel di saluran pencernaan yang menggerakkan dalam saluran pencernaan. Dengan demikian, bayi cepat lapar atau ingin makan karena pencernaannya semakin lancar.Air susu ibu (ASI) merupakan asupan nutrisi utama pada bayi khususnya bayi dibawah 6 bulan. ASI diproduksi atas hasil kerja gabungan antara hormone Oksitoksin, Prolaktin dan Reflek Let Down. Sehingga faktor psikologis ibu dan faktor bayi sangat berkaitan dengan produksi ASI. Penelitian ini merupakan penelitian analitik dengan jenis penelitian yang digunakan yaitu Quasy experimenntal (eksperimen semu) berupaya mengungkapkan hubungan sebab akibat antara variabel bebas (prediktor) denagn variabel tergantung (efek) dalam periode waktu tertentu. Populasi dalam penelitian ini adalah semua bayi 1-3 bulan di Puskesmas Cikampek Karawang.Pengambilan sampel dengan teknik purposive sampling berdasarkan kriteria inklusi dan eklusi. Untuk menganalisis pengaruh pijat bayi terhadap frekuensi dan durasi menyusu pada bayi 1-3 bulan di Puskesmas Cikampek Kabupaten Karawang dengan menggunakan Uji T test. Hasil penelitian diperoleh data bahwa ada pengaruh antara pijat bayi dengan frekuensi menyusu pada bayi dengan nilai $P(0,000)$ dan tidak ada pengaruh antara pijat bayi dengan durasi menyusu pada bayi ( $P$ value 0,563 ). Diharapkan bidan dapat terus memotivasi ibu untuk melakukan pijat bayi sehingga akan meningkatkan frekuensi menyusui pada bayinya dan memotivasi untuk tetap memberikan ASI Eklusif pada Bayinya.
\end{abstract}

Kata Kunci: Pijat bayi, frekuensi menyusu, durasi menyusu.

ABSTRACT

One of the benefits of baby massage is the increased appetite coupled with increased activity of the vagus nerves (the nervous system of the brain that works for the neck down to the chest and abdominal cavity) in moving peristaltic cells (cells in the digestive tract that move in the canal digestion, so the baby is hungry or wants to eat because the digestion is more fluent. Breast milk (ASI) is the main nutrient intake in infants, especially babies under 6 months, and is produced on the combined work of the hormone oxytocin, prolactin and reflux Let Down. Maternal psychological factors and infant factors are closely related to breast milk production This research is an analytical research with the type of research used Quasy experimenntal (quasi experiment) attempts to reveal the causal relationship between independent variables (predictors) with dependent variables (effects) over a period of time The population in this study are all infants 1-3 months in Puskesmas Cikampek Karawang.Pengambilan with purposive sampling technique based on inclusion and exclusion criteria. To analyze the effect of infant massage on the frequency and duration of breastfeeding in infants 1-3 months at Cikampek Community Health Center Karawang regency by using T test. The results showed that there was influence between infant massage and breastfeeding frequency in infants with $P$ value (0.000) and no influence between infant massage and breast feeding duration ( $P$ value 0,563). It is expected that midwives can continue to motivate mothers to do baby massage so that it will 
increase the frequency of breastfeeding in their babies and motivate to continue to give Exclusive Breast Milk to their babies.

Keywords: Infant massage, breastfeeding frequency, duration of breastfeeding

\section{PENDAHULUAN}

Kecemasan orang tua terfokus pada kenaikan berat badan bayi khususnya dalam tahun-tahun pertama kehidupannya (Roesli, 2001). Kenaikan berat badan bayi. sangat dipengaruhi oleh asupan nutrisi.

Pijat bayi merupakan sentuhan setelah kelahiran, serta dapat memberikan jaminan adanya kontak tubuh berkelanjutan yang dapat mempertahankan perasaan nyaman pada bayi. Terapi sentuh, terutama pijat pada bayi dapat menghasilkan perubahan fisiologis yang menguntungkan (Roesli, 2001)

Di Negara-negara maju, telah banyak dilakukan penelitian ilmiah yang mengungkap manfaat pijat bayi. Ibu-ibu di Negara-negara maju mulai merasakan manfaat besar dari pijat bayi sehingga hal itu dianggap penting dalam merawat bayi, disamping ASI eksklusif dan imunisasi.

Di Indonesia, pijat bayi mulai diperkenankan pada masyarakat luas (Subakti, 2008) Sebenarnya ilmu pijat bayi tradisional sudah lama dikenal, bahkan sampai sekarangpun masih dilakukan oleh dukun pijat bayi di daerah-daerah. Namun, pijat bayi yang dimaksud di sini adalah pijat bayi yang dilakukan oleh ibu, ayah atau anggota keluarga si bayi. ${ }^{13}$

Pijat bayi mudah dipelajari dan umumnya dengan beberapa kali latihan para orang tua sudah mahir, disamping murah karena hanya memerlukan minyak/baby oil, juga banyak manfaatnya. Dampak positif dari pijat bayi antara lain: menurunkan kadar hormone stress, peningkatan kadar zat daya tahan tubuh (immunoglobin), memperbaiki sirkulasi darah, merangsang fungsi pencernaan serta pembuangan, meningkatkan nafsu makan, mengubah gelombang otak yang dapat membuat bayi tidur lelap, meningkatkan aliran oksigen dan nutrisi menuju sel, meningkatkan kenaikan berat badan dan mengeratkan ikatan batin antara bayi dengan orang tua (bonding), meningkatkan volume $\mathrm{ASI}^{4}, 13$

Sebuah penelitian yang dilakukan Field dan Scafidi menunjukkan bahwa 20 bayi premature yang dipijat selama $3 \times 15$ menit setiap hari selama 10 hari mengalami peningkatan per hari $20 \%$ $47 \%$ lebih banyak daripada bayi yang tidak dipijat. Penelitian pada bayi cukup bulan berusia 1-3 bulan yang dipijat selama 6 minggu mengalami kenaikan berat badan yang lebih tinggi dari kelompok bayi yang tidak dipijat. ${ }^{4}$ Hasil penelitian Dieter JNI dkk menunjukkan bahwa terdapat peningkatan berat badan yang lebih pada bayi premature yang dipijat daripada bayi premature yang tidak dipijat. Penelitian Sunarsih $T$ menyatakan bahwa ada pengaruh pijat bayi terhadap peningkatan berat badan bayi usia 0-3 bulan di BPS Saraswati Sleman Yogyakarta. Lee HK menyatakan bahwa pijat bayi dapat meningkatkan berat badan bayi dan meningkatkan hubungan antara ibu dan bayi.

Salah satu dari manfaat pijat bayi yang telah disebutkan di atas adalah meningkatkan nafsu makan. Peningkatan nafsu makan ini ditambah dengan peningkatan aktivitas nervus vagus/saraf pengembara (system saraf otak yang bekerja untuk daerah leher ke bawah sampai dada dan rongga 
perut) dalam menggerakkan sel peristaltic (sel di saluran pencernaan yang menggerakkan dalam saluran pencernaan. Dengan demikian, bayi cepat lapar atau ingin makan karena pencernaannya semakin lancar (Subakti, 2008).

Sebuah penetian yang dilakukan oleh Fitriani dan nurhidayanti mendapatkan hasil bahwa ada hubungan antara pijat bayi dengan peningkatan nafsu makan pada bayi usia di atas 6 bulan.

Air susu ibu (ASI) merupakan asupan nutrisi utama pada bayi khususnya bayi dibawah 6 bulan. ${ }^{13}$ ASI diproduksi atas hasil kerja gabungan antara hormone Oksitoksin, Prolaktin dan Reflek Let Down. Sehingga faktor psikologis ibu dan faktor bayi sangat berkaitan dengan produksi ASI (Roesli, 2000)

\section{METODE}

Penelitian ini merupakan penelitian analitik dengan jenis penelitian yang digunakan yaitu Quasy experimental (eksperimen semu) menggunakan dua kelompok yaitu kelompok perlakuan dan kelompok kontrol. Bertujuan untuk mengetahui pengaruh pijat bayi terhadap peningkatan frekuensi dan durasi menyusu pada bayi usia 1-3 bulan.

Populasi dalam penelitian ini adalah semua bayi $1-3$ bulan di Puskesmas Cikampek Kabupaten Karawang. Cara pengambilan sampel menggunakan teknik purposive sampling, yaitu teknik penentuan sampel dengan pertimbangan tertentu berdasarkan kriteria inklusi dan eksklusi yang telah ditentukan. Kriteria Inklusi: Bayi baru lahir cukup bulan, berat badan normal $(\geq$ 2500 gram dan $\leq 4000$ gram), bayi sehat (Tidak ada kelainan) dan ASI eksklusif. Kriteria Eksklusi: Bayi premature, berat badan $\leq 2500$ gram atau $\geq 4000$ gram, bayi sakit, Tidak ASI eksklusif dan bayi piatu.

Sampel dibagi 2 kelompok yaitu kelompok perlakuan dan kelompok kontrol . Kelompok perlakuan diberikan perlakuan pijat bayi $2 \mathrm{x} /$ minggu selama 15 menit, kelompok kontrol diberikan perlakukan pijat bayi 1x/minggu selama 15 menit. Kemudian dilakukan observasi pada kedua kelompok tersebut. Penelitian ini juga menggunakan studi kohort. Besar. Perhitungan besar sampel dalam penelitian ini menggunakan rumus besar sampel untuk eksperimen diperoleh sampel sebesar 28 responden masing-masing baik pada kelompok perlakuan maupun kelompok kontrol, untuk mengurangi tingkat kesalahan ditambahkan $10 \%$ sehingga jumlah responden menjadi 30 responden untuk kelompok perlakuan maupun kontrol. Untuk menganalisi pengaruh pijat bayi terhadap peningkatan frekuensi dan durasi menyusu dilakukan dengan uji statistic parametric yaitu uji $\mathrm{T}$ test.

\section{HASIL DAN PEMBAHASAN}

Tabel 1 Distribusi Frekuensi Karakteristik Responden

\begin{tabular}{llcc}
\hline No & Karakteristik & \multicolumn{2}{c}{ Kelompok Perlakuan } \\
\cline { 3 - 4 } & & Frekuensi & Presentasi (\%) \\
\hline 1 & Umur & & \\
& 1 bulan & 28 & $46,7 \%$ \\
& 2 bulan & 19 & $31,7 \%$
\end{tabular}




\begin{tabular}{|c|c|c|c|}
\hline \multirow{4}{*}{2} & 3 bulan & 13 & $21,7 \%$ \\
\hline & Jenis Kelamin & & \\
\hline & Laki-laki & 29 & $48,3 \%$ \\
\hline & Perempuan & 31 & $51,7 \%$ \\
\hline \multirow[t]{3}{*}{3} & Status Sosial ekonomi & & \\
\hline & Tinggi & 13 & $21,7 \%$ \\
\hline & Rendah & 47 & $78,3 \%$ \\
\hline
\end{tabular}

Pada Tabel 1 dapat diketahui bahwa dari 60 responden sebagian besar berumur 1 bulan sebanyak 46,7 \% (28 responden), berjenis kelamin laki-laki sebanyak 48,3\% (29 responden) dan memiliki status social ekonomi rendah sebanyak 78,3\% (47 responden)

\section{Tabel 2 Distribusi Frekuensi Peningkatan Frekuensi Pada Kelompok Perlakuan Dan Kelompok Kontrol}

\begin{tabular}{clcccc}
\hline No & $\begin{array}{l}\text { Peningkatan rata- } \\
\text { rata Frekuensi } \\
\text { Menyusu (X/hari) }\end{array}$ & \multicolumn{2}{l}{ Kelompok Perlakuan } & \multicolumn{2}{l}{ Kelompok Kontrol } \\
\cline { 2 - 5 } & Frekuensi & Presentasi (\%) & Frekuensi & Presentasi (\%) \\
\hline 1 & 3 & $10 \%$ & 5 & $16,7 \%$ \\
2 & 10 & $33,3 \%$ & 14 & $46,7 \%$ \\
3 & 11 & $36,7 \%$ & 7 & $23,3 \%$ \\
& 4 & 4 & $13,3 \%$ & 4 & $13,3 \%$ \\
& 2 & $6,7 \%$ & 0 & 0 \\
\hline
\end{tabular}

Pada Tabel 2 dapat diketahui bahwa pada kelompok perlakuan sebagian besar responden mengalami peningkatan rata-rata frekuensi menyusu $2 \mathrm{x} /$ hari yaitu sebanyak $36,7 \% \quad(11$ responden $), 33,3 \% \quad(10$ responden) mengalami peningkatan 1x/hari, 13,3\% (4 responden) mengalami peningkatan $3 \mathrm{x} /$ hari, $6,7 \%$ ( 2 responden) mengalami peningkatan $4 \mathrm{x} /$ hari dan $10 \%$ (3 responden) tidak mengalami peningkatan frekuensi menyusu. Sedangkan pada kelompok kontrol sebagian besar mengalami peningkatan rata-rata frekuensi menyusu $1 \mathrm{x} /$ hari yaitu sebanyak 46,7 \% (14 responden), 23,3\% (7 responden) mengalami peningkatan 2x/hari, 13,3 \% (4 responden) mengalami peningkatan $3 \mathrm{x} /$ hari, $16,7 \%$ ( 5 responden) tidak mengalami peningkatan frekuensi menyusu.

Tabel 3 Distribusi Frekuensi Peningkatan Durasi Menyusu Pada Kelompok Perlakuan Dan Kelompok Kontrol

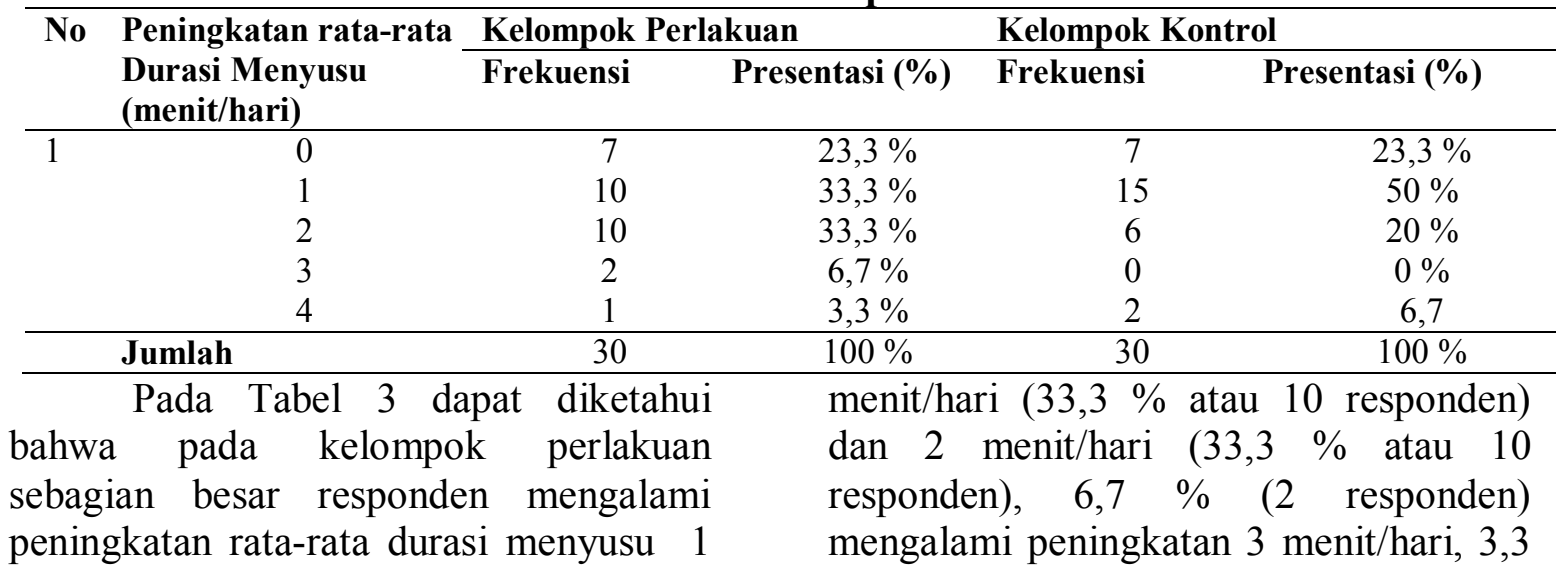


$\%$ ( 1 responden) mengalami peningkatan 4 menit/hari dan 23,3\% (7 responden) tidak mengalami peningkatan durasi menyusu. Sedangkan pada kelompok kontrol sebagian besar mengalami peningkatan rata-rata durasi menyusu 1 menit/hari yaitu sebanyak $50 \%$ (15 responden $), \quad 20 \% \quad$ (6 responden $)$ mengalami peningkatan 2 menit/hari, 6,7 $\%$ (2 responden) mengalami peningkatan 4x/hari, 23,3 \% ( 7 responden) tidak mengalami peningkatan frekuensi menyusu.

Tabel 4 Pengaruh Pijat Bayi Terhadap Peningkatan Frekuensi Menyusu Pada Kelompok Perlakuan dan Kelompok Kontrol

\begin{tabular}{|c|c|c|c|c|c|}
\hline \multirow{4}{*}{$\begin{array}{l}\text { Kelompo. Frekuensi Menyusu Pada Mg pertama } \\
\text { Perlakuar Frekuensi Menyusu Pada Mg ke emp }\end{array}$} & Mean & SD & SE & P Value & $\mathbf{N}$ \\
\hline & 15,5 & 1,72 & 0,31 & \multirow{5}{*}{0,000} & \multirow[t]{4}{*}{30} \\
\hline & & & & & \\
\hline & 17,23 & 1,57 & 0,29 & & \\
\hline Kelompo Frekuensi Menyusu Pada Mg pertama & 14,07 & 2,29 & 0,42 & & \\
\hline Kontrol Frekue & & & & & \\
\hline & 15,40 & 1,96 & 0,36 & & 30 \\
\hline \multirow{9}{*}{$\begin{array}{l}\text { Pada tabel } 4 \text { Diketahui bahwa } \\
\text { pada kelompok perlakuan, rata-rata } \\
\text { frekuensi menyusu pada minggu pertama } \\
\text { adalah } 15,50 \mathrm{kali} / \mathrm{hari} \text { dengan standar } \\
\text { deviasi } 1,72 \mathrm{dan} \text { frekuensi rata-rata } \\
\text { menyusu pada minggu ke empat adalah } \\
\text { 17,23kali/hari dengan standar devias } \\
\text { 1,57. sedangkan pada kelompok kontro } \\
\text { diperoleh hasil rata-rata frekuensi pada }\end{array}$} & & \multirow{9}{*}{\multicolumn{4}{|c|}{$\begin{array}{l}\text { minggu pertama adalah } 14,07 \mathrm{kali} / \text { hari } \\
\text { dengan standar deviasi } 2,29 \text { dan frekuensi } \\
\text { rata-rata pada minggu ke empat adalah } \\
\text { 15,40kali/hari dengan standar deviasi } \\
\text { 1,96. Hasil uji statistik didapatkan } p \text { value } \\
0,000 \text { maka dapat disimpulkan bahwa } \\
\text { terdapat perbedaan peningkatan frekuensi } \\
\text { menyusu pada kelompok perlakuan dan } \\
\text { kelompok kontrol. }\end{array}$}} \\
\hline & & & & & \\
\hline & & & & & \\
\hline & & & & & \\
\hline & & & & & \\
\hline & & & & & \\
\hline & & & & & \\
\hline & & & & & \\
\hline & & & & & \\
\hline
\end{tabular}

\section{Tabel 5 Pengaruh Pijat Bayi Terhadap Peningkatan Durasi Menyusu Pada Kelompok Perlakuan dan Kelompok Kontrol}

\begin{tabular}{|c|c|c|c|}
\hline Mean & SD & P Value & $\mathbf{N}$ \\
\hline $\begin{array}{lllll}\begin{array}{l}\text { Kelompok } \\
\text { Perlakuan }\end{array} & \begin{array}{l}\text { Durasi } \\
\text { pertama }\end{array} & \text { Menyusu } & \text { Pada } & \text { N. 14,77 } \\
\end{array}$ & 2,79 & 0,563 & 30 \\
\hline $\begin{array}{l}\text { Durasi Menyusu Pada Mg } 1 \text { 16,10 } \\
\text { empat }\end{array}$ & 3,07 & 0,56 & \\
\hline $\begin{array}{l}\text { Durasi } \\
\text { pertama }\end{array}$ & 3,29 & 0,60 & 30 \\
\hline $\begin{array}{l}\text { Durasi Menyusu Pada Mg } 115,60 \\
\text { empat }\end{array}$ & 3,57 & 0,65 & \\
\hline $\begin{array}{l}\text { Pada Tabel } 5 \text { : Diketahui bahwa } \\
\text { rata-rata durasi menyusu pada bayi yang } \\
\text { dilakukan pemijatan minggu pertama } \\
\text { adalah } 14,77 \text { menit/hari dengan standar } \\
\text { deviasi } 2,79 \text { dan pada minggu keempat } \\
\text { rata-rata durasi menyusu pada bayi adalah } \\
\text { 16,10 menit/hari. Sedangkan pada bayi } \\
\text { yang tidak dilakukan pemijatan durasi }\end{array}$ & \multicolumn{3}{|c|}{$\begin{array}{l}\text { menyusu pada minggu pertama adalah } \\
14,43 \text { meni/harit dengan standar deviasi } \\
3,29 \text { dan rata-rata menyusui pada minggu } \\
\text { keempat adalah } 15,60 \text { menit/hari dengan } \\
\text { standar deviasi } 3,57 \text {. Hasil uji statistic } \\
\text { didapatkan } p \text { value } 0,563 \text { maka dapat } \\
\text { disimpulkan tidak terdapat perbedaan } \\
\text { peningkatan durasi menyusu pada }\end{array}$} \\
\hline
\end{tabular}


kelompok perlakuan dan kelompok kontrol.

Hasil penelitian menunjukkan pada kelompok perlakuan sebagian besar responden mengalami peningkatan rata-rata frekuensi menyusu $2 \mathrm{x} /$ hari yaitu sebanyak 36,7 $\% \quad(11$ responden $), \quad 33,3 \% \quad(10$ responden) mengalami peningkatan $1 \mathrm{x} /$ hari, $13,3 \quad \% \quad(4$ responden $)$ mengalami peningkatan $3 \mathrm{x} /$ hari, $6,7 \%$ ( 2 responden) mengalami peningkatan $4 \mathrm{x} /$ hari dan $10 \%$ (3 responden) tidak mengalami peningkatan frekuensi menyusu. Sedangkan pada kelompok

Hasil penelitian ini sejalan dengan teori yang menyatakan bahwa pijat bayi dapat meningkatkan nafsu makan. Pijat bayi menyebabkan bayi menjadi lebih rileks dan dapat beristirahat dengan efektif sehingga ketika bayi terbangun akan membawa energi cukup untuk beraktivitas. dengan aktivitas yang optimal, bayi menjadi cepat lapar sehingga nafsu makannya meningkat. Peningkatan nafsu makan ini juga ditambah dengan peningkatan aktivitas nervus vagus (system sarat otak yang bekerja untuk daerah leher ke bawah sampai dada dan rongga perut) dalam menggerakkan sel peristaltic untuk mendorong makanan ke saluran pencernaan. Dengan demikian, bayi lebih cepat lapar atau ingin makan karena pencernaannya semakin lancar (Roesli, 2008)

Hal ini sejalan juga dengan hasil penelitian Fitriani dan Nurhidayanti yang menyatakan bahwa ada hubungan antara pijat bayi dengan peningkatan nafsu makan. Penelitian Erlian menyatakan bahwa ada pengaruh pijat bayi usia 0-4 bulan terhadap peningkatan frekuensi menyusui. Penelitian Falikhah dan Hidayat menyatakan bahwa terdapat kontrol sebagian besar mengalami peningkatan rata-rata frekuensi menyusu $1 \mathrm{x} /$ hari yaitu sebanyak 46,7 $\% \quad(14$ responden), 23,3 \% (7 responden) mengalami peningkatan $2 x /$ hari, $\quad 13,3 \quad \% \quad(4$ responden $)$ mengalami peningkatan $3 \mathrm{x} /$ hari, 16,7 $\%$ ( 5 responden) tidak mengalami peningkatan frekuensi menyusu. Hasil uji statistik didapatkan $\mathrm{p}$ value 0,000 maka dapat disimpulkan bahwa terdapat perbedaan peningkatan frekuensi menyusu pada kelompok perlakuan dan kelompok kontrol.

pengaruh pijat bayi terhadap frekuensi menyusui bayi usia 0-3 bulan.

Hasil penelitian ini juga menunjukkan bahwa pada kelompok perlakuan sebagian besar responden mengalami peningkatan rata-rata durasi menyusu 1 menit/hari $(33,3 \%$ atau 10 responden) dan 2 menit/hari (33,3\% atau 10 responden), 6,7\% (2 responden) mengalami peningkatan 3 menit/hari, 3,3 \% (1 responden) mengalami peningkatan $4 \mathrm{menit} / \mathrm{hari}$ dan $23,3 \% \quad$ (7 responden) tidak mengalami peningkatan durasi menyusu. Sedangkan pada kelompok kontrol sebagian besar mengalami peningkatan rata-rata durasi menyusu 1 menit/hari yaitu sebanyak $50 \%$ (15 responden), $20 \quad \% \quad$ (6 responden) mengalami peningkatan 2 menit/hari, $6,7 \% \quad(2$ responden $)$ mengalami peningkatan $4 x$ /hari, $23,3 \%$ ( 7 responden) tidak mengalami peningkatan frekuensi menyusu. Hasil uji statistik didapatkan $\mathrm{p}$ value 0,563 maka dapat disimpulkan bahwa tidak terdapat perbedaan peningkatan durasi menyusu pada kelompok perlakuan dan kelompok kontrol.

Hasil penelitian ini tidak sejalan dengan teori yang menyatakan bahwa pijat bayi dapat meningkatkan gerak peristaltik pada saluran 
pencernaan sehingga makanan akan dicerna lebih cepat. Hal ini yang menyebabkan bayi menjadi cepat lapar. (Subakti, 2008).

Hasil penelitian ini tidak sejalan dengan hasil penelitian Fitriani dan nurhidayanti yang menyatakan bahwa ada hubungan antara pijat bayi dengan peningkatan nafsu makan.

Banyak faktor yang dapat mempengaruhi durasi menyusu pada bayi, baik faktor ibu (kelelahan, aktivitas ibu dll) maupun faktor bayi (posisi menyusu yang tidak tepat dll)

\section{SIMPULAN}

Hasil penelitian ini menunjukkan bahwa pijat bayi berpengaruh terhadap peningkatan frekuensi menyusu pada bayi usia $1-3$ bulan ( $p$ value $=0,000$ ) tetapi tidak berpengaruh terhadap durasi menyusu pada bayi usia 1-3 bulan $(p$ value $=0,563)$

\section{DAFTAR PUSTAKA}

Dieter JNI, Field T, Hernandez M, Eugene, Redzepi M. 2014. Stable preterm infant gain more weight and sleep less after five days of massage therapy. Journal of pediatric psychology vol 28 , no 6 .

Erlian E. 2012. Pengaruh pijat bayi terhadap peningkatan frekuensi menyusui dan berat badan bayi di Rumah Sakit Sitti Khadijah 1 Makassar, Skripsi.

Fraser DM. 2003. Myles buku ajar bidan. Jakarta: EGC.

Fitriani L, Nurhidayanti N. 2007. Pengaruh pijat bayi terhadap peningkatan nafsu makan pada bayi usia di atas 6 bulan. 2007.
Field T, Scafidi \& Schanberg. 1987. Massage of preterm newborns to improve growth \& development. Journal Pediatric Nursing vol 13.

Falikhah A, Hidayat A. 2015. Pengaruh pijat bayi terhadap frekuensi menyusui pada bayi 03 bulan di BPS Dini Melani Condong Catur Sleman Yogyakarta, Naskah Publikasi.

Kementerian Kesehatan RI. 2013. Rencana kerja pembinaan gizi masyarakat tahun 2013. Jakarta.

Kementerian Kesehatan RI. Profil kesehatan provinsi perkabupaten. 2013 [diunduh 20 oktober 2014]. Tersedia dari: www.bankdata.depkes.go.id.

Kundarti FI. 2011. Pengaruh pemijatan terhadap kenaikan berat badan dan lama tidur bayi usia 1 sampai 3 bulan. Jurnal penelitian kesehatan suara forikes vol II.

Lutfianti T, Ain $H$, Astuti NP. Pengaruh pijat bayi terhadap peningkatan berat badan bayi usia 1-6 bulan di posyandu melati desa Banjararum singosari malang.

Lee HK. The effects of infant massage on weight, height and motherinfant interaction. Journal of Korean academy of nursing vol 36, no 8

Roesli U. 2001. Pedoman pijat bayi premature dan bayi usia $0-3$ bulan. Jakarta: Niaga swadaya. 
Roesli U, 2000. Mengenal ASI Eksklusif seri 1. Jakarta: Trubus Agriwidya

Subakti Y, Anggraini DR. 2008. Keajaiban pijat bayi dan balita. Jakarta: PT wahyumedia.

Setiawan A, Saryono. 2010. Metodologi penelitian kebidanan. Yogyakarta: Nuha medika.
Varney H, Kriebs JM, Gegor CL. 2008. Buku ajar asuhan kebidanan. Vol 2. Jakarta: EGC. 